Gut, 1977, 18, 19-22

\title{
Controlled trial of synthetic D-penicillamine and prednisone in maintenance therapy for active chronic hepatitis
}

\author{
R. B. STERN ${ }^{1}$, S. P. WILKINSON, P. J. N. HOWORTH, AND ROGER WILLIAMS \\ From the Liver Unit and Department of Chemical Pathology, King's College Hospital and Medical \\ School, Denmark Hill, London
}

SUMMARY In view of promising, but uncontrolled, reports of the use of D-penicillamine in active chronic hepatitis, a randomised, prospective, controlled trial of this drug against prednisone was carried out. Of the 35 patients entered, 18 received D-penicillamine (increasing to $1.2 \mathrm{~g}$ daily) and 17 prednisone (15 $\mathrm{mg}$ daily). In all patients the disease had already been brought under biochemical control with corticosteroids. During the first year of the trial, the treatment of nine patients in the D-penicillamine group was discontinued (two because of lack of disease control and seven because of side-effects) compared with six patients in the prednisone group (four because of lack of disease control, one because of side-effects, and one because of the development of carcinomatosis. Detailed statistical analysis of the liver function tests in the patients remaining in the trial at the end of the year showed no significant differences. D-penicillamine is associated with a higher frequency of side-effects than is prednisone. However, in some patients it is as satisfactory as prednisone in keeping the disease under control.

The currently adopted treatment for active chronic hepatitis, based on the results of a number of controlled trials (Cook et al., 1971; Murray-Lyon et al., 1973; Summerskill et al., 1975), is with corticosteroids, often in combination with azathioprine (Summerskill et al., 1975). Although this treatment reduces the overall mortality and suppresses the inflammatory component of the liver lesion, there is no evidence to suggest that it affects established cirrhosis. Furthermore, the side-effects from both corticosteroids and azathioprine have been a problem in these series. Over the last eight years a number of workers, mainly from continental Europe, have reported promising results with D-penicillamine, but so far no controlled trials have been reported. In the controlled trial reported here, the value of D-penicillamine was compared with prednisone in the maintenance therapy of active chronic hepatitis, once the disease had been brought under control initially with larger doses of corticosteroids.

'Present address: Middlesex Hospital, Mortimer Street, London WC1.

Received for publication 6 September 1976

\section{Methods}

Patients

Thirty-five patients with active chronic hepatitis were selected from those seen in the Liver Clinic between December 1973 and October 1974. Active chronic hepatitis was diagnosed on the history of at least three months' duration with features, on liver biopsy, of chronic aggressive hepatitis, with or without cirrhosis. The patients were entered to the trial only when their disease had been brought under control biochemically as evidenced by a serum of bilirubin of less than $43 \mu \mathrm{mol} / 1$, and serum aspartate transaminase $<150 \mathrm{IU} / \mathrm{l}$. These levels were reached with corticosteroids given initially in doses of $30 \mathrm{mg}$ prednisone daily reducing to $15 \mathrm{mg}$, with some patients receiving $75 \mathrm{mg}$ azathioprine daily in addition. Some patients had previously been diagnosed as having the disease, and were already on maintenance doses of prednisone-for example, 15 mg daily. In those cases where the criteria for biochemical control were already satisfied, they were randomised without any initial period of highdosage prednisone. 
The patients were then allocated to two groups using a random number system, one group on a maintenance treatment schedule of $1200 \mathrm{mg} \mathrm{D}$ penicillamine daily and the other on $15 \mathrm{mg}$ prednisone daily in divided doses. We did not attempt to make the trial double-blind because side-effects, if they arose, were likely to be distinctive.

The group taking D-penicillamine was started on a daily dose of $600 \mathrm{mg}$ gradually increasing over three months to the full maintenance dose. The dosage of corticosteroids was gradually being reduced during the same three months' period, so that all patients in this group were off steroids after three months. Patients with cirrhosis (determined histologically or by laparoscopy), and those with $\mathrm{HBsAg}$ in the serum, were randomised separately. In addition to clinical observation in the outpatient department, the patients also had a blood count, standard liver function tests, and blood caeruloplasmin levels estimated at three monthly intervals.

If the disease became out of control (serum bilirubin above $60 \mu \mathrm{mol} / 1$ or aspartate transaminase above $250 \mathrm{IU} / 1$ on two successive occasions within 14 days) or if evidence of severe drug toxicity side-effects developed, patients were withdrawn from the trial. Drug toxicity side-effects necessitating withdrawal from the trial were considered to be bleeding or perforated peptic ulcer, vertebral collapse, diabetes requiring insulin, or psychosis in the prednisone group; and skin rash, leucopenia $(<2000 / \mathrm{cu} \mathrm{mm})$ thrombocytopenia $(<40000 / \mathrm{cu}$ $\mathrm{mm}$ ), intolerable nausea and vomiting, or proteinuria ( $>1 \mathrm{~g} / 24 \mathrm{~h}$ ) in the D-penicillamine group.

Results were analysed using Student's $t$ test, and the Chi-square test with Yates' correction where necessary.

\section{Results}

Thirty of the patients already had cirrhosis, and two had HBsAg in the blood. Twelve patients in the prednisone group and 12 in the D-penicillamine group had previously been diagnosed as having active chronic hepatitis and had therefore been treated with corticosteroids, in doses up to $15 \mathrm{mg}$ prednisone daily, for two years before entry to the trial. These patients in no way differed from those previously untreated at the time of entry. Six patients in the D-penicillamine group and five in the prednisone group had had no previous treatment, and their disease needed to be brought under initial control with $30 \mathrm{mg} /$ day of prednisone before randomisation. A comparison of age, sex, serum bilirubin, aspartate transaminase, albumin, gamma globulin, caeruloplasmin levels, previous treatment with corticosteroids, and the presence of cirrhosis in the two groups showed no significant difference. As the trial progressed, nine of the 18 patients from the D-penicillamine group and six of the 17 patients from the prednisone group had to be withdrawn (Table 1). In each case the manifestations of drug

Table 1 Patients withdrawn from trial, with duration of treatment and reasons for withdrawal

\begin{tabular}{|c|c|c|c|c|}
\hline $\begin{array}{l}\text { Case } \\
\text { no. }\end{array}$ & $\begin{array}{l}\text { Age } \\
\text { (yr) }\end{array}$ & $\operatorname{Sex}$ & $\begin{array}{l}\text { Weeks } \\
\text { in trial }\end{array}$ & Reasons for withdrawal \\
\hline \multicolumn{5}{|c|}{ Prednisone group } \\
\hline 1 & 48 & $\mathbf{F}$ & 12 & Lack of disease control \\
\hline 2 & 18 & $\mathbf{M}$ & 36 & Lack of disease control \\
\hline 3 & 70 & $\mathbf{F}$ & 28 & Carcinomatosis \\
\hline 4 & 32 & $\mathbf{F}$ & 3 & Bleeding gastric erosion \\
\hline 5 & 17 & $\mathbf{F}$ & 4 & Lack of disease control \\
\hline 6 & 21 & $\mathbf{M}$ & 24 & Lack of disease control \\
\hline \multicolumn{5}{|c|}{ Penicillamine group } \\
\hline 1 & 74 & $\mathbf{F}$ & 16 & Nausea and metallic taste \\
\hline 2 & 35 & $\mathbf{F}$ & 20 & Lack of disease control \\
\hline 3 & 35 & $\mathbf{M}$ & 20 & Nausea and rash \\
\hline 4 & 21 & $\mathbf{M}$ & 36 & Rash \\
\hline 5 & 24 & $\mathbf{F}$ & 12 & Rash and proteinuria \\
\hline 6 & 54 & $\mathbf{F}$ & 12 & Vasculitis requiring steroids \\
\hline 7 & 44 & $\mathbf{F}$ & 3 & Nausea and vomiting \\
\hline 8 & 71 & $\mathbf{F}$ & 16 & Rash \\
\hline 9 & 63 & $\mathbf{M}$ & 4 & Rash \\
\hline
\end{tabular}

toxicity side-effects disappeared when the drug was stopped. Only two patients were withdrawn from the D-penicillamine group because of lack of control of disease activity, and seven developed drug toxicity side-effects. The nine patients from this group who remained in the trial showed no deterioration in liver function tests at the end of one year's continuous treatment.

In contrast, only one patient from the prednisone group was withdrawn because of drug toxicity sideeffects, but four were withdrawn because the disease became out of control and one because of the development of carcinomatosis. Although the reasons for withdrawal were different in the two groups, these differences did not achieve statistical significance, and neither did the total number of withdrawals.

An analysis of the mean values for serum bilirubin, aspartate transaminase, and $\alpha$ globulin levels of the patients who remained in the two treatment groups after one year's continuous treatment also showed no significant statistical differences. The initial values for these patients on entry to the trial were also essentially similar. The mean serum caeruloplasmin in the D-penicillamine group was lower after a year's treatment than on entry, but this did not reach statistical significance (Table 2).

A comparison of patients with or without cirrhosis, or HBsAg, within and between the two groups, showed no significant differences in the number of 
Table 2 Comparison of mean values $\pm S D$ for standard liver function tests and serum caeruloplasmin levels at entry to trial and after one year of continuous treatment

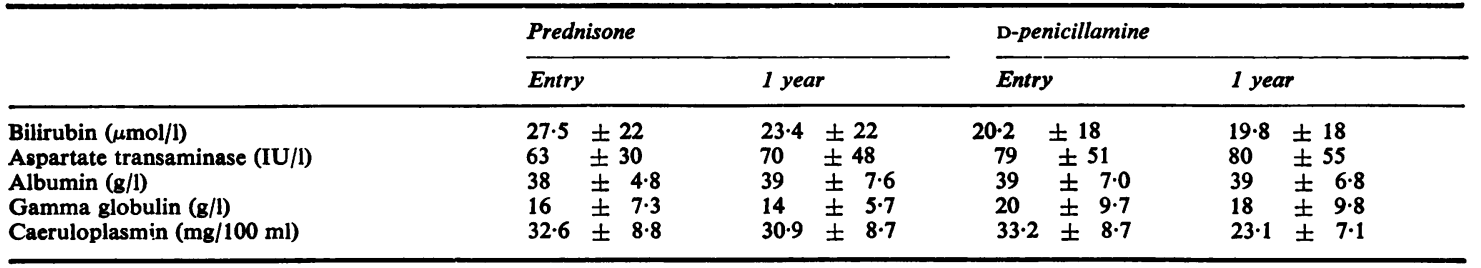

patient withdrawals, the incidence of drug toxicity, or changes in liver function tests.

\section{Discussion}

Despite treatment with corticosteroids (whether or not in combination with azathioprine), between $5 \%$ and $20 \%$ of patients with active chronic hepatitis die within two years of diagnosis (Murray-Lyon et al., 1975; Summerskill et al., 1975), and there is no evidence that corticosteroids or immunosuppressive treatment affects cirrhosis once it is established. The latter is already present in many patients by the time the diagnosis is made with variously reported figures from about a quarter to over half the cases (Summerskill et al., 1975). In the present series the frequency of cirrhosis was even higher $(80 \%)$ but many of our patients had already had the disease for many years with previous immunosuppressive treatment.

D-penicillamine may, like levamisole, have an immunostimulant action (Huskisson et al., 1976), although it is known for its inhibitory effect on collagen synthesis, increasing the ratio of uncrosslinked fibrils (Nimni and Bavetta, 1965; Harris and Sjoerdsma, 1966; Francis et al., 1973). This has led to the hope that its administration, if started early enough in the course of active chronic hepatitis, might help to prevent the development of cirrhosis. There is already considerable literature on the use of D-penicillamine in uncontrolled active chronic hepatitis. Alexander and Kludas (1969) used the drug in two patients with subacute hepatic necrosis, and Wiontzek (1970) in one with hepatitis and bridging necrosis. Five of the six patients treated by Lange et al. (1971) and all 11 treated by Schnack (1971) showed improvements in liver function tests and histology. In the three larger series which have been reported, Lange (1973) found clinical, biochemical, and histological improvement in nine of 21 patients treated with $1.8 \mathrm{~g}$ D-penicillamine a day, and Alexander and Willie (1974) found similar improvements in 15 of 34 patients, but in no case was cirrhosis reversed and 12 patients had to stop the drug because of side-effects. In 60 patients treated by Wildhirt (1974) $38 \%$ showed biochemical improvement, although in $25 \%$ side-effects were a problem.

Unfortunately, it is difficult to assess these results as none of the previous series was controlled. The present series is the first in which a prospective, randomly-allocated, controlled trial has been carried out. The results provide no evidence that the disease was less well controlled on D-penicillamine $1.2 \mathrm{~g} /$ day than on prednisone $15 \mathrm{mg} /$ day. Indeed, control appeared slightly better on D-penicillamine, although this could not be proven statistically. However, sideeffects with this drug proved a severe problem, necessitating withdrawal of $39 \%$ of the patients treated. Of these, proteinuria and nephrotic syndrome (Goldberg et al., 1963; Yonis and Karp, 1963; Sternlieb, 1966; Rosenberg and Hayslett, 1967; Crawhall and Watts, 1968) are perhaps the most serious, although only one case was seen in the present series and this was reversed when the drug was withdrawn. A wide variety of skin lesions and occasionally fatal blood dyscrasias have also been described (Walshe, 1968; Andrews et al., 1973). Loss of taste acuity or a metallic taste in the mouth are common, occurring in up to a third of patients (Scheinberg, 1968; Andrews et al., 1973) but may be reversed with copper sulphate. Side-effects may be minimised by starting with a low dosage, as was done in the present series, and recent studies in rheumatoid arthritis have also shown that doses as low as $600 \mathrm{mg}$ daily produce just as good a therapeutic effect as $1200 \mathrm{mg}$ with fewer side-effects (Dixon et al., 1975).

In conclusion, it is clear that, because of the frequency of toxicity side-effects, D-penicillamine, at least in the present dosage, cannot be considered to be the treatment of choice in the maintenance therapy of patients with active chronic hepatitis. However, if prednisone (with or without azathioprine) becomes contraindicated because of the development of complications such as diabetes, osteoporosis, gastric ulceration, etc (or of leucopenia or neutropenia attributable to azathioprine), or if the 
disease fails to come under control, it would seem on the basis of our findings to be a useful alternative drug.

We are grateful to the Biochemistry Department at the Institute of Neurology for the caeruloplasmin determinations, to Dr G. Kristen (Chemiewerk Homburg, Frankfurt), and Professor W. Braasch (Bayer Leverkusen) for supplies of D-penicillamine, and to Dr Ralph Kohn of Advisory Services (Clinical and General, London) for support and advice.

\section{References}

Alexander, M. and Kludas, M. (1969). KollagensyntheseHemmung durch D-Penicillamin bei chronisch aggressiver Hepatitis. Munchener Medizinische Wochenschrift, 111, 847-850.

Alexander, M. and Wille, G. (1974). D-Penicillamin-Therapie bei Lebererkrankungen. Munchener Medizinische Wochenschrift, 116, 211-216.

Andrews, F. M. Golding, D. N., Freeman, A. M., Golding, J. R., Day, A. T., Hill, A. G. S., Camp, A. V., LewisFaning, E., and Lyle, W. H. (1973). Controlled trial of D-penicillamine in severe rheumatoid arthritis. Lancet, 1, 275-280.

Cook, G. C., Mulligan, R., and Sherlock, S. (1971). Controlled prospective trial of corticosteroid therapy in active chronic hepatitis. Quarterly Journal of Medicine, 40, 159185.

Crawhall, J. C. and Watts, R. W. E. (1968). Some complications observed in the treatment of cystinuria with $D$ penicillamine and $\mathrm{N}$-acetyl D-penicillamine. Postgraduate Medical Journal (Penicillamine supplement), pp. 8-11.

Dixon, A. St. J., Davies, J., Dormandy, T. L., Hamilton, E. B. D., Holt, P. J. L., Mason, R. M., Thompson, M., Weber, J. C. P., and Zutshi, D. W. (1975). Synthetic D-penicillamine in rheumatoid arthritis. Annals of Rheumatic Diseases, 34, 416-421.

Francis, M. J. O., Mowat, A. G., and Smith, R. (1973). Effects of D-penicillamine on polymeric structural collagen of skin. Lancet, 1, 773-774.

Goldberg, A., Smith, J. A., and Lochhead, A. C. (1963).
Treatment of lead-poisoning with oral penicillamine. British Medical Journal, 1, 1270-1275.

Harris, E. D. and Sjoerdsma, A. (1906). Effect of penicillamine on human collagen and its possible application to treatment of scleroderma. Lancet, 2, 996-999.

Huskisson, E. C., Dieppe, P. A., Scott, J., Trapnell, J., Balme, H. W., and Willoughby, D. A. (1976). Immunostimulant therapy with levamisole for rheumatoid arthritis. Lancet, 1, 393-395.

Lange, J. (1973). 3eme Symposium Internationale sur la Maladie de Wilson. Paris. (Unpublished).

Lange, J., Schumacher, K., and Witscher, H. P. (1971). Die Behandlung der chronisch-aggressiven Hepatitis mit D-Penicillamin. Deutsche Medizinische Wochenschrift, 96, 139-145.

Murray-Lyon, I. M., Stern, R. B., and Williams, R. (1973). Controlled trial of prednisone and azathioprine in active chronic hepatitis. Lancet, 1, 735-737.

Nimni, M. E. and Bavetta, L. A. (1965). Collagen defect induced by penicillamine. Science, 150, $905-906$.

Rosenberg, L. E. and Hayslett, J. P. (1967). Nephrotoxic effects of penicillamine in cystinuria. Journal of the American Medical Association, 201, 698-699.

Scheinberg, I. H. (1968). Toxicity of penicillamine. Postgraduate Medical Journal (Penicillamine supplement), pp. 11-13.

Schnack, H. (1971). Zur Therapie aktiver Zirrhosen mit Penicillamin. Wiener Medizinische Wochenschrift, 121, 900-902.

Sternlieb, I. (1966). Penicillamine and the nephrotic and the nephrotic syndrome: results in patients with hepatolenticular degeneration. Journal of the American Medical Association, 198, 1311-1312.

Summerskill, W. H. J., Korman, M. G., Ammon, H. V., and Baggenstoss, A. H. (1975). Prednisone for chronic active liver disease: dose titration, standard dose, and combination with azathioprine compared. Gut, 16, 876-883.

Walshe, J. M. (1968). Toxic reactions to penicillamine in patients with Wilson's Disease. Postgraduate Medical Journal (Penicillamine supplement), pp. 6-8.

Wildhirt, E. (1974). Therapie ohronischer Leberkrankheiten mit D-penicillamin. Munchener Medizinische Wochenschrift, 116, 217-220.

Wiontzek, H. (1970). Behandlung der chronisch aggressiven Hepatitis mit D-Penicillamin. Medizinische Welt, 21, 14191423.

Yonis, I. Z. and Karp, M. (1963). Chelating agents in Wilson's disease. Lancet, 2, 689. 